\title{
ANTECEDENTS AND CONSEQUENCES OF UNIVERSITY BRAND IDENTIFICATION
}

\author{
Roshan Bhadel ${ }^{[1], * \text { Govinda Tamang }^{[2]}}$ \\ 1. School of Management Tribhuvan University \\ 2. Central Department of Management Tribhuvan university
}

\begin{abstract}
This research aims to examine the impact of university brand personality, university brand knowledge and university brand prestige on university identification. The study also aims to examine the impact of university identification on advocacy intentions, suggestions for improvements, university affiliation and participation in future activities. In order to execute the study, descriptive research design has been implemented. The study is based on primary data collected through structured questionnaire. A total of 285 respondents have been taken for this study.

The findings of the study revealed that all three antecedents; university brand personality, university brand knowledge and university brand prestige has significant positive impact on university identification. Among three antecedents, university brand knowledge has the greatest impact on university
\end{abstract}


identification. Similarly, the findings also revealed that there is significant positive impact of university identification on advocacy intentions, suggestions for improvements, university affiliation and participation in future activities. Likewise, the greatest consequence of university identification is advocacy intentions.

Keywords: University identification, Antecedents, Consequences, Social identity theory, Higher education institutions

\section{*Corresponding-author}

\section{Introduction}

As higher education continues to grow and becomes increasingly globalized, increased competition and reduced government funds place more significant pressure on institutions to practice branding (Nguyen et al., 2016; Joseph et al., 2012). Through branding, an institution can differentiate itself, avoiding competition and increasing the sense of belongingness (Frølich \& Stensaker, 2010).

'Branding' of universities is a recent marketing tool that aims to attract, engage and retain students and position universities in the competitive higher education environment (Wilson \& Elliot, 2016; Sultan \& Yin Wong, 2014). Branding establishes quality or legitimacy and displays prestige (Chapleo, 2011). Branding conveys values to potential supporters revealing why the organization is worthy of backing and provides a mental hook for donors (Sargeant \& Ford, 2007). Branding helps institutions to promote prestigious and distinctive identities (Frølich \& Stensaker, 2010).

Further, branding strategies also help universities to improve funding through greater numbers of domestic and international students. It also covers rising tuition fees, increased promotional costs and attracts top academics, executives, donations research money, media attention and strategic partners (Nguyen et al., 2016; Joseph et al., 2012). Perhaps the most important benefit of branding specifically in higher education is the 
ability to offer students and alumni a sense of belonging through "life-long membership" (Curtis, T., Abratt, R., \& Minor, W., 2009).

The feeling of belonging instills a sense of identification. Identification can be defined as the tendency to define the self in terms of an association with an organization or brand (Jiménez-Castillo et al., 2013). Identification triggers an individual to psychologically perceive a bond with the group such that their fate is "intertwined with the fate of the group" (Ashforth \& Mael, 1989). Consumer brand identification refers to the individual's sense of belongingness with a particular brand. In a similar way, university brand identification is a specific form of social identification characterized by students' attachment or belongingness with the university (Mael \& Ashforth, 1992).

University brand identification is considered as an important driver of customers' attitudes and behaviors towards the university. Students who strongly identify with the university are likely to be more committed and perform beyond their role requirements (Mael \& Ashforth, 1992). University identification results in students engaging in a variety of supportive behaviors such as advocacy intentions, university affiliation, suggestions for improvements, and participation in future university activities (Balaji et al., 2016).

In addition, university identification is related to prospective students' behavioral intentions towards the university (Wilkins \& Huisman, 2013). Among the current students, university identification is found to influence their perceptions towards university merchandise, overall attitude and support towards the university (Jiménez-Castillo et al., 2013). While these studies confirm that university identification can enhance students' perception towards the university, there is a lack of understanding of how university identification is formed and how this influences students' behavior towards the university Balaji et al., (2016). In the context of Nepal, there are only limited studies carried out in identifying the antecedents and consequences of university brand identification. Therefore, this research has following research objectives:

1. To examine the antecedents of university brand identification 
2. To investigate the role of university identification on students' supportive behaviors towards the university.

\section{Theoretical Background}

\subsection{Social Identity Theory}

Kuenzel \& Vaux Halliday,(2008) mentioned that the concept of brand identification is based on social identity theory. Social identity theory (Parcel, 1981), is based on the premise that individuals define their own identities with regard to certain groups and such identification enhances their self- identity. Such identification with a specific group is directly related to the motive of enhancing self-identity and self-regard. Individuals self-classify into any number of social groups or categories (Lund Dean \& Jolly, 2012), which could include labels such as 'management student' or 'future captains of industry' (Zambo et al., 2013). Classification enables people to order the social environment and to locate themselves in it (Kim et al., 2010), which is a relational and comparative process that results in an individual's recognition of both in- and out-groups (Jungert, 2013).

According to social identity theory, people tend to classify themselves and others into various social categories, such as nationality, religious affiliation, socio-economic class and academic ability (Tajfel \& Turner, 1985). Tajfel (1978) defines social identity as, 'that part of an individual's self-concept which derives from his/her knowledge of his/her membership in a social group together with the value and emotional significance attached to that membership'. Social identification, therefore, is the perception of belongingness and sense of oneness with a group. Individuals define themselves relative to the individuals in other categories, so social identification is largely relational and comparative (Wilkins \& Huisman, 2013).

\subsection{University identification}

University identification is a specific form of social identification, characterized by students' attachment or belongingness with the university. According to social identity theory, university identification allows students to enhance their self-concept or self-image 
by associating with the university. Students who strongly identify with the university are more likely to be committed and perform beyond their role requirements. This allows students to represent and support their university (Mael \& Ashforth, 1992).

Ahearne et al. (2005) conducted a study among 2000 high-prescribing physicians to identify antecedents and consequences of customer-company identification. Findings suggest that stronger the customer-company identification (CCI), more often customers recommend the company to others. Further, customers who identify with a company express their identification by performing extra role behaviors, such as engaging in WOM activities, recruiting customers, suggesting improvement ideas to the company, and communicating proactively about anticipated problems. C. Bhattacharya and Sen (2004) also emphasized positive WOM as one of the key important behavioral outcomes of CCI.

C. B. Bhattacharya and Sen (2003) argued that when customers identify with companies, they become "champions of the companies" and enthusiastically promote the company and its products to others.

Hong and Yang (2009) conducted a study to examine the effect of organizational reputation and relational satisfaction on customers' positive word of mouth (WOM) intentions and the critical mediation role of customer-company identification in such effects. Results indicate that customer-company identification mediates the influence of organizational reputation on positive WOM intentions. Further, findings suggest that, when customers perceive a company's reputation as favorable, they are more likely to identify with the company, as well as engage in positive WOM intentions.

Balaji et al. (2016), conducted a study to examine the antecedents of university identification and to investigate the role of university identification on students' supportive behaviors towards the university. Findings show that prestige and knowledge are influential drivers of students' perception of identification with the university. In addition, students who identify with their university, perceive their destiny as interweaved with the university which drives their desire to engage in university supportive behaviors. Further, universities should engage in branding activities that develop strong student-university identification in order to enhance the students' university supportive behaviors. 
In a study conducted by Tuškej et al. (2013), to investigate the relationship between congruity of consumer and brand values, brand identification, brand commitment and word of mouth found that congruity of consumer and brand values tends to have positive influence on consumers' identification. Consumers who identify with a brand tend to commit stronger to a brand and generate positive word of mouth. The results show that consumers' identification fully mediates the impact of value congruity on brand commitment.

In a study conducted by Stephenson and Yerger (2014) to analyze the effect of brand identification on supportive behaviors, found that brand identification is significantly and positively related to brand-supportive behaviors of alumni such as positive word of mouth, recruitment efforts, and wearing school-related clothing. Brand identification had a stronger effect on promotional behaviors than for competitive attitude.

Wilkins and Huisman (2013) conducted a study among 407 students in the United Arab Emirates (UAE) to discover the extent to which prospective higher education students still in secondary education might identify with international branch campuses and the extent to which organizational identification and its individual components might influence students' behavioral intentions towards these institutions. The findings revealed that students who identify with a particular university are more likely to engage in behaviors that benefit the university, such as choosing to study at that institution, engaging in supportive behaviors that promote or serve the institution, or simply by positively interacting or involving themselves with the institution.

In a study conducted by Kim et al. (2010) to analyze the effect of identification with a university on intentions to support the university, it was found that individuals who identified with the university showed strong intentions to support the university such as positive word of mouth and making alumni donations.

Platow et al. (2012) concluded that students who identify strongly as a student in their discipline area are more likely to develop an intrinsic interest in their subject and 
program and will seek to share the interests they perceive to be held by other students in their discipline, influencing their commitment and approach to learning.

Wilkins et al. (2015) conducted a study among 437 students to investigate the effects of social and organizational identifications on student commitment, achievement and satisfaction in higher education. Findings revealed that organizational identification is a stronger predictor of student commitment, achievement and satisfaction and organizational identification can influence the attitudes and behavior of higher education students, as it has been found to do with employees and consumers.

Fazli-Salehi et al. (2020) conducted a study to evaluate the antecedents and outcomes of brand identification with Apple products on purchase intention among Iranian consumers. The results of the study revealed that brand identification positively affects both purchase intention and brand loyalty.

Lam et al. (2012) conducted a longitudinal study to examine the dynamics of consumer brand identification (CBI) and its antecedents in the context of the launch of a new brand. Three focal drivers of CBI with a new brand were examined, namely: perceived quality (the instrumental driver), self-brand congruity (the symbolic driver), and consumer innate innovativeness (a trait based driver). Findings revealed that consumer brand identification rises after the introduction but eventually declines.

\subsection{Antecedents of university brand identification}

\section{University brand personality}

University personality refers to the extent to which students consider the personality traits of the university in terms of being friendly, stable, practical, and warmth (Sung \& Yang, 2008). University brand personality is based on the idea that people select products and/or brands that correspond to their self-concept (Usakli \& Baloglu, 2011).

Sampaio et al. (2012) mentioned that students' direct interaction with academic and administrative staffs leads to the development of a specific university brand 
personality. Universities can also develop brand personalities indirectly through its logo, prospectus, heritage, history, architecture, and location (Melewar \& Akel, 2005).

When students evaluate the university personality as favourable or congruent, they are more likely to develop a supportive attitude of belongings to the university (Sung \& Yang, 2008). Polyorat (2011) reports that brand personality dimensions of sincerity and competence have a greater impact on university identification than sophistication and excitement. Stephenson and Yerger (2014) found that the university brand assessed in terms of being distinctive, unique, positive image, and appealing has a positive influence on university identification. Stokburger-Sauer et al. (2012) conducted a study to identify the drivers of consumer-brand identification. Six drivers of consumer-identification were examined; brand-self similarity, brand distinctiveness, brand prestige, brand social benefits, brand warmth and memorable brand experiences. The findings revealed that all five of these antecedents have stronger causal relationships with CBI except for brand prestige when consumers have higher involvement with the brand's product category.

\section{University brand knowledge}

University brand knowledge is the students' perception of how knowledgeable s/he is about the communications, values and benefits associated with the university (Sujan, 1985). Balaji et al. (2016) conducted a study to examine the antecedents of university identification and to investigate the role of university identification on students' supportive behaviors towards the university. Findings revealed that university brand knowledge has a significant impact of on university identification.

Brewer \& Zhao (2010) report that university brand awareness which is considered as the knowledge about what the university represents, its mission, goals, major campus events is positively associated with students' opinion towards the brand and overall reputation of the institution. Chawla \& Srivastava (2016) conducted a study to examine the antecedents of organizational identification of postgraduate students and its impact on institutions. Findings revealed that universities which share information with students about 
its development activities, and consistently provide academic performance feedback tend to motivate their students to identify with the university.

\section{University brand prestige}

University brand prestige refers to relative high status position of the university. It can be defined as the degree to which the institution is well regarded both in absolute and comparative terms (Mael \& Ashforth, 1992). Sung \& Yang (2008) have found positive relationship between university brand prestige and alumni involvement and financial donations, recruitment of students and academicians, and students supportive behaviors. Social identification theory also suggests that prestigious identity of the university allows students to enhance their self-esteem and meet their self enhancement needs (Elbedweihy \& Jayawardhena, 2014; Mael \& Ashforth, 1992).

Tuškej \& Podnar (2018) conducted a study among 464 consumers to explore the antecedents of consumer-brand identification (CBI). Four antecedents of CBI were taken into account namely brand anthropomorphism, consumer-brand engagement, consumer's skepticism and brand prestige. Findings revealed that there is significant influence of brand prestige on CBI and CBI has a strong, positive influence on brand loyalty. Stephenson and Yerger (2014) conducted a study to explore whether brand identification elicited brandsupportive behaviors from university alumni. Three antecedents of identification were taken into account; prestige, interpretation of brand and satisfaction. Findings revealed that all three antecedents were significantly related to identification and interpretation of brand was the most influential antecedent of identification.

Kuenzel \& Vaux Halliday (2008) conducted a study to analyze the influence of prestige, satisfaction and communication on brand identification. Findings reflected that prestige had a significant impact on brand identification; higher the prestige of the brand, more the customers identified themselves with the brand. Porter et al. (2011) conducted a study among 114 alumni from 74 different colleges to identify the antecedents and outcomes of college identification. Results indicated that perceived athletic prestige and perceived academic prestige had significant relationship with college identification. 
Hawass (2020) conducted a study to examine the antecedents of student-university identification in Egyptian higher education sector. Findings revealed that university reputation is directly associated with student-university identification.

\subsection{Consequences of university brand identification}

\section{Advocacy intentions}

Advocacy intentions refer to the act of promoting and safeguarding the interest of the university. It includes positively speaking about the university, representing the university to external publics, recruiting for the university, and lending support for the university (Balaji et al., 2016). Prior research has reported that identity salience leads to both direct and indirect promotions by the students such as talking up the university to people they know, bringing up the university in a positive way in conversations with

friends, and speaking favorably about the university in social situations (Porter et al., 2011; Stephenson \& Yerger, 2014).

In a study conducted by Kuenzel \& Vaux Halliday (2008) in the United Kingdom (UK) to analyze the effect of brand identification on word-of-mouth and brand repurchase, it was found that brand identification has positive effects on word of mouth and repurchase intentions. Higher the identification of customers with a brand, the more they are willing to recommend and to consider repurchasing the brand. Similarly, Porter et al. (2011) in their study also found that identification positively affected giving intentions to athletics, academic areas and general university funds as well as alumni promotion of the university. In a study conducted by Stokburger-Sauer et al. (2012), it was found that there is positive link between CBI and its pro-brand consequences, such as loyalty and advocacy.

\section{Suggestions for improvement}

Suggestions for improvement are a form of voice where students voluntarily share their opinions and contribute ideas to help the university provide better service to the students (Balaji et al., 2016). Research from Blau (1964) report that students who have strong identification with the university will provide high level of feedback to the university since university identification helps students achieve self-esteem and students 
reciprocate by offering suggestions for improvements to the university. Beaudoin (2005) suggests that student voice plays a crucial role in university improvement, student motivation and engagement.

\section{University affiliation}

University affiliation refers to the extent to which students personally identify with the university through the display of university logo, university stickers, and university merchandise. Stephenson \& Yerger (2014), found that university identification is positively related to promotion strategy of wearing clothing with the school's logo. Affiliation is a visual form of promotion strategy whereby students publicly display their attachment with the university to friends and others (Balaji et al., 2016). Oja et al. (2015) found that after successful game students show a greater tendency to wear university clothing to display their identification with the university.

\section{Participation in future activities}

Participation in university future activities relates to the willingness of students to attend future events and functions held and sponsored by the university. Helgesen and Nesset (2007) in their study found a positive influence of university college image on student's probability of attending the new courses and further education at the same university. Brown and Mazzarol (2008) found that students' perception of the university image in terms of the study environment, practicality, and conservatism is positively related to repurchase intentions through satisfaction. Perin et al.(2012) found that affective commitment as determined by a strong sense of identification with the university determines the students' intentions to attend future events and courses in the university. Balaji et al. (2016) also found significant positive relationship between university identification and participation in future activities of the university. 


\subsection{Theoretical Framework}

Independent Variables

Dependent variables

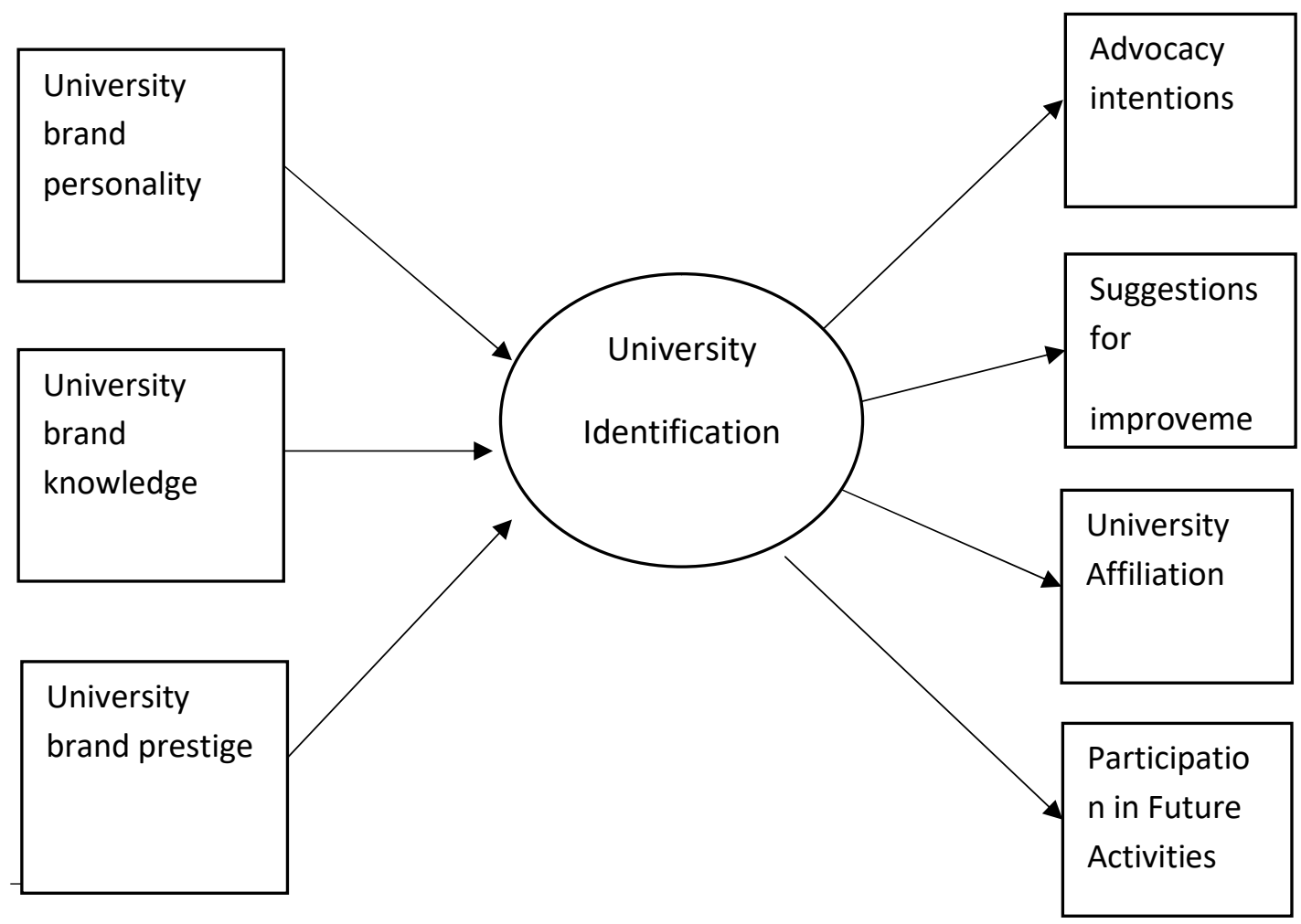

Fig. 1: Theoretical framework of the study

Figure 1 shows various antecedents and consequences of university identification. Here, the independent variables are various antecedents of university identification such as university brand personality, university brand knowledge and university brand prestige. Likewise, the dependent variable of this study is various consequences of university identification such as advocacy intentions, suggestions for improvement, university affiliation, and participation in future activities. The conceptual framework has been adopted from Balaji et al., (2016) and modified for this study. 


\section{Research methodology}

This study was based on primary data. The research design was both descriptive and analytical. The google form was developed consisting 27 items under both antecedents and consequences constructs ( see table 1) and was sent via researcher's email to current undergraduate and graduate level students as well as alumni of graduate and undergraduate level program from different universities of Nepal.

At first the pilot test was carried out in order to finalize the questionnaire. After collecting 52 responses, the researcher conducted reliability and validity test. For reliability test, the cronbach alpha was computed and found at least 0.7 which confirmed the internal consistency in the constructs. The factor analysis was conducted to test the unidimensionality of the construct and found to be valid.

The contact email of the respondents was obtained by referral from existing contacts with researcher. Altogether the researcher was able to collect 285 responses through google survey during the onging COVID-19 pandemic. The obtained CSV file was imported to Statistical Package for Social Science (SPSS) software for the analysis as per the stated objectives.

The summated scale was developed and assessed the attitude of the respondents towards each construct. Further correlation matrix of both antecedents of university identification and consequences of university identification were computed to examine the relationships. Finally the Seven simple linear regression models were built in order to study the effect of the antecedents on university identification and the effect of university identification on the consequences.

\section{Table 1}

Constructs, no of items and its respective sources

\begin{tabular}{cll}
\hline Constructs & No of items & Adapted from \\
\hline University brand personality & 3 & Sung and Yang (2008) \\
University brand knowledge & 4 & Baumgarth and Schmidt (2010)
\end{tabular}




\begin{tabular}{lll}
\hline \multicolumn{1}{c}{ Constructs } & No of items & Adapted from \\
\hline University brand prestige & 4 & Mael and Ashforth (1992) \\
University identification & 4 & Jones and Kim (2011) \\
Advocacy intentions & 3 & Zeithaml et al. (1996); Stephenson \\
& & and Yerger (2014) \\
Suggestions for improvement & 3 & Bove et al. (2009) \\
University affiliation & 3 & Johnson and Rapp (2010) \\
Participation in future activities & 3 & Bove et al. (2009) \\
\hline
\end{tabular}

\section{Data analysis and results}

\subsection{Descriptive Statistics}

Table 2

Descriptive test for the factors

\begin{tabular}{|c|c|c|c|c|c|}
\hline \multicolumn{6}{|l|}{ Descriptive Statistics } \\
\hline & $\mathrm{N}$ & Minimum & Maximum & Mean & $\begin{array}{c}\text { Std. } \\
\text { Deviation }\end{array}$ \\
\hline $\begin{array}{l}\text { University Brand Personality } \\
\text { (UBP) }\end{array}$ & 285 & 3 & 15 & 10.6 & 2.63 \\
\hline $\begin{array}{l}\text { University Brand Knowledge } \\
\text { (UBK) }\end{array}$ & 285 & 4 & 20 & 14.62 & 3.06 \\
\hline $\begin{array}{l}\text { University Brand Prestige } \\
\text { (UBP) }\end{array}$ & 285 & 4 & 20 & 15.52 & 3.53 \\
\hline University Identification (UI) & 285 & 4 & 20 & 13.62 & 3.36 \\
\hline Advocacy Intentions (AI) & 285 & 3 & 15 & 11.08 & 2.88 \\
\hline $\begin{array}{ll}\text { Suggestions } & \text { for } \\
\text { Improvements (SFI) }\end{array}$ & 285 & 3 & 15 & 11.76 & 2.46 \\
\hline University Affiliation (UA) & 285 & 3 & 15 & 8.99 & 2.86 \\
\hline $\begin{array}{l}\text { Participation in Future } \\
\text { Activities (PFA) }\end{array}$ & 285 & 3 & 15 & 10.97 & 2.51 \\
\hline
\end{tabular}


Table 2 exhibits the mean score given by the respondents to each of the five-point Likert scale questions where 1 represents strong disagreement and 5 represents strong agreement and the variation in responses, as represented by standard deviation, regarding overall antecedents and consequences of university identification. On an average, most of the respondents show agreement towards the statements of university brand personality, knowledge, prestige, advocacy intention, suggestions for improvements, university affiliation, and participation in future activities.

\subsection{Correlation Analysis}

The simple correlation of each of the antecedents UBP,UBK, and UBPR with UI is provided in table 3 and that of each of consequences AI , SFI, UA, PFA with UI is in table 4.

Table 3

Correlation Matrix of antecedents of university identification

\begin{tabular}{lllll}
\hline & UI & UBP & UBK & UBPR \\
\hline UI & 1 & & & \\
UBP & $0.608^{* *}$ & 1 & & \\
UBK & $0.642^{* *}$ & $0.691^{* *}$ & 1 & 1 \\
UBPR & $0.614^{* *}$ & $0.669^{* *}$ & $0.711^{* *}$ & 1 \\
\hline
\end{tabular}

** Correlation is significant at the 0.01 level (2-tailed).

The table 3 clearly indicates that here is significant relationship of each of antecedents UBP, UBK, and UBPR with UI $(\mathrm{P}=0.01)$. However, the relationship of UBK with UI demonstrates slightly higher than that of other antecedents UBP and UBPR.

Table 4

Correlation Matrix of consequences of university identification

\begin{tabular}{llllll}
\hline & AI & SFI & UA & PFA & UI \\
\hline AI & 1 & & & & \\
\hline
\end{tabular}




\begin{tabular}{llllll}
\hline & AI & SFI & UA & PFA & UI \\
\hline SFI & $.265^{* *}$ & 1 & & & \\
UA & $.320^{* *}$ & $.361^{* *}$ & 1 & & \\
PFA & $.359^{* *}$ & $.522^{* *}$ & $.425^{* *}$ & 1 & 1 \\
UI & $.654^{* *}$ & $.374^{* *}$ & $.384^{* *}$ & $.406^{* *}$ & 1 \\
\hline ** Corrention &
\end{tabular}

** Correlation is significant at the 0.01 level (2-tailed).

The table 4 depicts that there is significant relationship of UI with each of the consequences AI, SFI, UA, and PFA ( $\mathrm{P}=0.01)$. However, relationship with AI demonstrates highest that others.

\subsection{Regression analysis}

The first three simple linear regression models show the impact of the three antecedents UBP, UBK, and UBPR on UI. The next four simple linear regression models show the effect of university identification on consequences AI, SFI, UA and PFA.

\begin{tabular}{|l|l|l|l|l|}
\hline Model & Regression equation & F $(1,283)$ & R-Square & P-Value \\
\hline 1 & $\mathrm{UI}=1.344+0.584(\mathrm{UBP})$ & 165.570 & 0.369 & 0.000 \\
\hline 2 & $\mathrm{UI}=0.824+0.707(\mathrm{UBK})$ & 198.640 & 0.412 & 0.000 \\
\hline 3 & $\mathrm{UI}=1.137+0.585(\mathrm{UBPR})$ & 171.393 & 0.377 & 0.000 \\
\hline 4 & $\mathrm{AI}=1.151+0.746(\mathrm{UI})$ & 211.542 & 0.428 & 0.000 \\
\hline 5 & $\mathrm{SFI}=2.680+0.364(\mathrm{UI})$ & 46.096 & 0.14 & 0.000 \\
\hline 6 & $\mathrm{UA}=1.513+0.435(\mathrm{UI})$ & 49.052 & 0.148 & 0.000 \\
\hline 7 & $\mathrm{PFA}=2.283+0.404(\mathrm{UI})$ & 55.896 & 0.165 & 0.000 \\
\hline
\end{tabular}

All three antecedents UBP, UBK and UBPR have significant impact on university identification $(\mathrm{P}<0.001)$. However, total variation in mean scale of $\mathrm{UI}$ has been explained more by the regression equation of UBK that comparing to UBP and UBPR. 
The UI has significant impact on all consequences AI, SFI, UA and PFA $(\mathrm{P}<0.001)$. However, total variation in mean scale of $\mathrm{AI}$ has been explained more by the regression equation.

\subsection{Discussion}

Literature in organizational behavior and marketing indicates that individuals who strongly identify with a brand or an organization perceive it as part of their self and express this association through various supportive behaviors (Elbedweihy \& Jayawardhena, 2014). Extending this argument to the case of HEI, the study of Balaji et al. (2016) found that university identification positively influences both low-to-medium supportive behaviors such as suggestions for improvement and university affiliation as well as high-intensity behaviors such as advocacy intentions and participation in future university activities.

The study revealed that university brand personality has significant positive impact on university identification. When students evaluate the university personality as favourable or congruent, they are more likely to develop a supportive attitude of belongings to the university. The university brand assessed in terms of being stable, practical and friendly has a positive impact on university identification. The findings of this study are consistent with the findings of Sung \& Yang (2008), Stephenson and Yerger (2014) and Stokburger-Sauer et al. (2012). However, the findings differ with the study conducted by Balaji et al. (2016) which concluded that university brand personality did not have a significant impact on university identification.

The study also revealed that university brand knowledge has significant positive impact on university identification. University brand awareness which is considered as the knowledge about what the university represents, its mission, goals, major campus events, positively impacts identification with the university. The findings of this study is similar to the findings of Balaji et al. (2016), Brewer \& Zhao (2010) and Chawla \& Srivastava (2016)

The study also revealed that university brand prestige has significant positive impact on university identification. The prestigious identity of the university allows students to enhance their self-esteem and meet their self enhancement needs. Hence, higher 
the prestige of the university brand, more the students identified themselves with the university. The findings of this study is similar to the findings of Balaji et al. (2016), Hong and Yang (2009), Sung \& Yang (2008), Tuškej \& Podnar (2018), Stephenson and Yerger (2014), Kuenzel \& Vaux Halliday (2008), Porter et al. (2011) and Hawass (2020).

Our findings differ from the study of Ahearne et al. (2005), which revealed that construed external image does not significantly influence customer-company identification.

The findings also revealed that university identification has significant positive impact on advocacy intentions. Identification with the university leads to both direct and indirect promotions by the students such as talking about the university to people they know, bringing up the university in a positive way in conversations with friends, and speaking favorably about the university in social situations. The findings of the study are consistent with the findings of Porter et al. (2011), Stephenson \& Yerger (2014), Kuenzel \& Vaux Halliday (2008), Wilkins and Huisman (2013), Kim et al. (2010) and StokburgerSauer et al. (2012).

The findings also revealed that university identification has significant positive impact on suggestions for improvements. Students who have strong identification with the university will provide high level of feedback to the university since university identification helps students achieve self-esteem and students reciprocate by offering suggestions for improvements to the university. The findings of the study are consistent with the findings of Balaji et al. (2016) and Blau (1964).

The findings also revealed that university identification has significant positive impact on university affiliation. Students who identify with the university publicly show their attachment with the university through the display of university logo, university stickers, and university merchandise to friends and others. The findings of the study are consistent with the findings of Stephenson \& Yerger (2014) and Balaji et al. (2016).

The findings also revealed that university identification has significant positive impact on participation in future activities. Students who identify with the university show the willingness to attend future events and functions held and sponsored by the university. 
The findings of the study are consistent with the findings of Brown and Mazzarol (2008), Perin et al. (2012) and Balaji et al. (2016). The findings also revealed that there is no significant differences in university identification across gender and profession. However, there is significant differences in university identification across educational level of attainment, affiliated university, stream of education and age.

\subsection{Conclusion}

The present research was carried out to identify antecedents and consequences of university identification. For this purpose, the present researcher had taken in account three antecedents of university identification i.e. university brand personality, university brand knowledge and university brand prestige. Similarly, four consequences were taken into account i.e. advocacy intentions, suggestions for improvements, university affiliation and participation in future activities. Further, this study has identified which antecedent has greatest impact on university identification. Similarly, the greatest consequence of university identification has also been identified in this study.

The findings of the study revealed that all three antecedents has significant positive impact on university identification. Likewise, the findings also revealed that all the antecedents are positively correlated with university identification. Among three antecedents, university brand knowledge has the greatest impact on university identification. Similarly, all four consequences are positively correlated with university identification. Likewise, the greatest consequence of university identification is advocacy intentions. The findings also revealed that there is significant positive impact of university identification on advocacy intentions, suggestions for improvements, university affiliation and participation in future activities.

\section{REFERENCES}

Ahearne, M., Bhattacharya, C. B., \& Gruen, T. (2005). Antecedents and Consequences of Customer-Company Identification: Expanding the Role of Relationship Marketing. Journal of Applied Psychology, 90(3), 574-585. 
Ashforth, B. E., \& Mael, F. (1989). Social Identity Theory and the Organization. Academy of Management Review, 14(1), 20-39.

Balaji, M. S., Roy, S. K., \& Sadeque, S. (2016). Antecedents and consequences of university brand identification. Journal of Business Research, 69(8), 3023-3032.

Beaudoin, N. (2005). Elevating student voice. How to enhance participation, citizenship, and leadership. Larchmont: Eye On Education.

Bhattacharya, C. B., \& Sen, S. (2003). Consumer-Company Identification: A Framework for Understanding Consumers' Relationships with Companies. Journal of Marketing, 67(2), 76-88.

Bhattacharya, C., \& Sen, S. (2004). Doing Better at Doing Good: When, Why, and How Consumers Respond to Corporate Social Initiatives. California Management Review, 47(1), 9-24.

Blau, P.M. (1964). Exchange and power in social life. New York, NY: Wiley

Brewer, A., \& Zhao, J. (2010). The impact of a pathway college on reputation and brand awareness for its affiliated university in Sydney. International Journal of Educational Management, 24(1), 34-47.

Chapleo, C. (2011). Exploring rationales for branding a university: Should we be seeking to measure branding in UK universities? Journal of Brand Management, 18(6), 411422.

Chawla, D., \& Srivastava, J. (2016). Antecedents of Organizational Identification of Postgraduate Students and Its Impact on Institutions. Global Business Review, 17(1), 176-190.

Curtis, T., Abratt, R., \& Minor, W. (2009). Corporate Brand Management in Higher Education: The Case of ERAU. Journal of Product and Brand Management, 18(6), 404-413. 
Elbedweihy, A. M., \& Jayawardhena, C. (2014). Consumer-brand identification: A social identity based review and research directions. The Marketing Review, 14(2), 205-228.

Elbedweihy, A. M., Jayawardhena, C., Elsharnouby, M. H., \& Elsharnouby, T. H. (2016). Customer relationship building: The role of brand attractiveness and consumerbrand identification. Journal of Business Research, 69(8), 2901-2910.

Fazli-Salehi, R., Azadi, M., Torres, I. M., \& Zúñiga, M. N. (2020). Antecedents and Outcomes of Brand Identification with Apple Products among Iranian Consumers. Journal of Relationship Marketing, 20(2), 135-155.

Frølich, N., \& Stensaker, B. (2010). Student recruitment strategies in higher education: promoting excellence and diversity? International Journal of Educational Management, 24(4), 359-370.

Hawass, H. H. (2020). The antecedents of student-university identification: an investigation into the Egyptian higher education sector. Middle East J. of Management, 7(1), 17.

Helgesen, Ø., \& Nesset, E. (2007). What accounts for students' loyalty? Some field study evidence. International Journal of Educational Management, 21(2), 126-143.

Hong, S. Y., \& Yang, S. U. (2009). Effects of Reputation, Relational Satisfaction, and Customer-Company Identification on Positive Word-of-Mouth Intentions. Journal of Public Relations Research, 21(4), 381-403.

Jiménez-Castillo, D., Sánchez-Fernández, R., \& Iniesta-Bonillo, M. N. (2013). Segmenting university graduates on the basis of perceived value, image and identification. International Review on Public and Nonprofit Marketing, 10(3), 235-252.

Johnson, J. W., \& Rapp, A. (2010). A more comprehensive understanding and measure of customer helping behavior. Journal of Business Research, 63(8), 787-792.

Jones, R., \& Kim, Y. K. (2011). Single-brand retailers: Building brand loyalty in the offline environment. Journal of Retailing and Consumer Services, 18(4), 333-340. 
Jungert, T. (2013). Social identities among engineering students and through their transition to work: a longitudinal study. Studies in Higher Education, 38(1), 39-52.

Kim, T., Chang, K., \& Jae Ko, Y. (2010). Determinants of organisational identification and supportive intentions. Journal of Marketing Management, 26(5-6), 413-427.

Kuenzel, S., \& Vaux Halliday, S. (2008). Investigating antecedents and consequences of brand identification. Journal of Product \& Brand Management, 17(5), 293-304.

Lam, S. K., Ahearne, M., Mullins, R., Hayati, B., \& Schillewaert, N. (2012). Exploring the Dynamics of Antecedents to Consumer-Brand Identification with a New Brand. Journal of the Academy of Marketing Science, 41(2), 234-252.

Lund Dean, K., \& Jolly, J. P. (2012). Student Identity, Disengagement, and Learning. Academy of Management Learning \& Education, 11(2), 228-243.

Mael, F., \& Ashforth, B. E. (1992). Alumni and their alma mater: A partial test of the reformulated model of organizational identification. Journal of Organizational Behavior, 13(2), 103-123.

Melewar, T., \& Akel, S. (2005). The role of corporate identity in the higher education sector. Corporate Communications: An International Journal, 10(1), 41-57.

Nguyen, B., Yu, X., Melewar, T., \& Hemsley-Brown, J. (2016). Brand ambidexterity and commitment in higher education: An exploratory study. Journal of Business Research, 69(8), 3105-3112.

Oja, B. D., Bass, J. R., \& Gordon, B. S. (2015). Conceptualizing employee identification with sport organizations: Sport Employee Identification (SEI). Sport Management Review, 18(4), 583-595.

Parcel, T. L. (1981). Differentiation Between Social Groups: Studies in the Social Psychology of Intergroup Relations.H. Tajfel. American Journal of Sociology, 86(5), 1193-1194.

Perin, M. G., Sampaio, C. H., Simões, C., \& de Pólvora, R. P. (2012). Modeling antecedents of student loyalty in higher education. Journal of Marketing for Higher Education, 22(1), 101-116. 
Platow, M. J., Mavor, K. I., \& Grace, D. M. (2012). On the role of discipline-related selfconcept in deep and surface approaches to learning among university students. Instructional Science, 41(2), 271-285.

Porter, T., Hartman, K., \& Johnson, J. S. (2011). Books and balls: antecedents and outcomes of college identification. Research in Higher Education Journal, 13(1), $1-14$.

Sampaio, C. H., Perin, M. G., Simões, C., \& Kleinowski, H. (2012). Students' trust, value and loyalty: evidence from higher education in Brazil. Journal of Marketing for Higher Education, 22(1), 83-100.

Sargeant, A., \& Ford, J. B. (2007). The Power of Brands. Stanford Social Innovation Review, 5(1), 41-47.

Stephenson, A. L., \& Yerger, D. B. (2014). Does brand identification transform alumni into university advocates? International Review on Public and Nonprofit Marketing, 11(3), 243-262.

Stokburger-Sauer, N., Ratneshwar, S., \& Sen, S. (2012). Drivers of consumer-brand identification. International Journal of Research in Marketing, 29(4), 406-418.

Sujan, M. (1985). Consumer Knowledge: Effects on Evaluation Strategies Mediating Consumer Judgments. Journal of Consumer Research, 12(1), 31.

Tajfel, H. (1978). Social categorization, social identity and social comparison. In H. Tajfel (Ed.), Differentiation between social groups: Studies in the social psychology of intergroup relations (pp. 61-76). London: Academic Press.

Tajfel, H., \& Turner, J.C. (1985). The social identity theory of intergroup behavior. In S. Worchel \& W.G. Austin (Eds.), Psychology of intergroup relations (pp. 7-24). Chicago, IL: Nelson-Hall.

Tuškej, U., \& Podnar, K. (2018). Exploring selected antecedents of consumer-brand identification. Baltic Journal of Management, 13(4), 451-470.

Tuškej, U. š., Golob, U. ̌̌., \& Podnar, K. (2013). The role of consumer-brand identification in building brand relationships. Journal of Business Research, 66(1), 53-59. 
Usakli, A., \& Baloglu, S. (2011). Brand personality of tourist destinations: An application of self-congruity theory. Tourism Management, 32(1), 114-127.

Wilkins, S., Butt, M. M., Kratochvil, D., \& Balakrishnan, M. S. (2015). The effects of social identification and organizational identification on student commitment, achievement and satisfaction in higher education. Studies in Higher Education, 41(12), 2232-2252.

Wilkins, S., \& Huisman, J. (2013). The components of student-university identification and their impacts on the behavioural intentions of prospective students. Journal of Higher Education Policy and Management, 35(6), 586-598.

Wilson, E. J., \& Elliot, E. A. (2016). Brand meaning in higher education: Leaving the shallows via deep metaphors. Journal of Business Research, 69(8), 3058-3068.

Zambo, D., Buss, R. R., \& Zambo, R. (2013). Uncovering the identities of students and graduates in a CPED-influenced EdD program. Studies in Higher Education, 40(2), 233-252.

Zeithaml, V. A., Berry, L. L., \& Parasuraman, A. (1996). The Behavioral Consequences of Service Quality. Journal of Marketing, 60(2), 31-46. 